
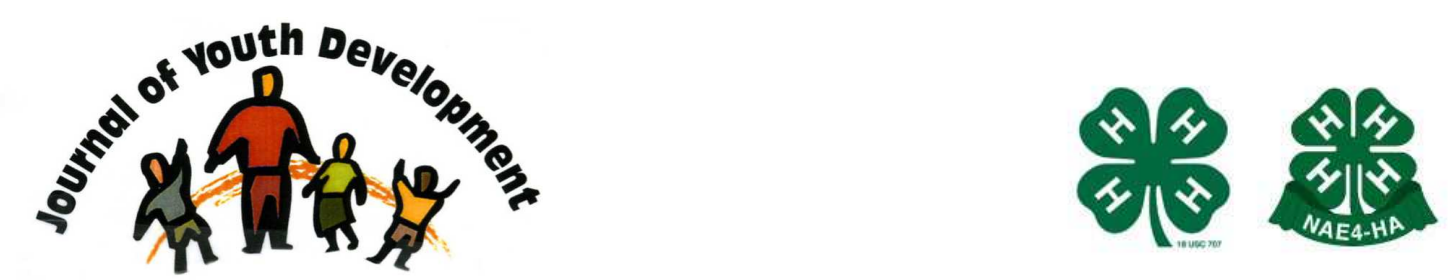

Bridging Research \& Practice

\title{
Life Skill Influence of Consumer Decision Making Program: Intensity and Breadth
}

\author{
Carrie Ann Olson \\ Center for Youth Development \\ University of Minnesota Extension \\ Morris, MN \\ Olson166@umn.edu
}

Sara R. Croymans

Center for Family Development University of Minnesota Extension

Morris, MN

Croym001@umn.edu

Kangting Ji

Center for Family Development University of Minnesota Extension

St. Paul, MN

jixxx062@umn.edu 


\title{
JOURNAL OF YOUTH DEVELOPMENT \\ bridging research and practice

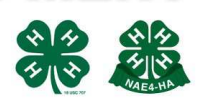

Volume 9, Number 3, Fall 2014

Article 140903FA002

\section{Life Skill Influence of Consumer Decision Making Program: Intensity and Breadth}

\author{
Carrie Ann Olson, Sara R. Croymans and Kangting Ji \\ University of Minnesota Extension
}

\begin{abstract}
The study presented in this paper focuses on an important aspect of life-event decision making: Consumer Decision Making. The purpose of the reported research was to ascertain if there is correlation between participating in the 4-H Consumer Decision Making (CDM) Program and life skill development. The study identified twelve life skills. The research hypothesis was that participants involved in multiple opportunities of the CDM program will report higher levels of positive life skill development than individuals reporting minimal involvement. Participants reported the 4-H CDM Program influenced development of decision making, critical thinking, and useful/ marketable life skills. The study investigated the relationship between member participation in eight core CDM program opportunities in Minnesota 4-H and life skill development. The study found that county fair project exhibit, county day camp, state consumer decision making educational activity/field trip, and consumer decision making judging contests have significant influence on life skills. It was determined that participants involved in more opportunities (6-8) reported greater influence on life skill development than participants in only 1-2 program opportunities.
\end{abstract}

\section{Introduction}

The mission of 4-H is to "empower youth to reach their full potential, working and learning in partnership with caring adults" (National 4-H Council, 2011). Over the years, numerous studies have been conducted to determine the impact of 4- $\mathrm{H}$ on participants and it has been found that active participation in 4-H programs contribute to improved quality of life in family, community and various life skills (Astroth, \& Haynes, 2002; Goodwin, et al., 2005; McKinley, 1999; Mulroy, \& Kraimer-Rickaby, 2006). Additional studies have evaluated specific 4-H programming efforts to identify life skill development, including service learning programs (Stafford, Boyd, \& Linder, 2003), camping programs (Klem, \& Nicholson, 2008), livestock projects and judging programs 
(Boleman, Cummings, \& Briers, 2004; Lange, 2004; Nash, \& Sant, 2005; Rusk, Martin, Talbert, \& Balschweid, 2002; Ward, 1996); and consumer decision making programs (Olson, \& Croymans, 2008). In addition, some studies have compared life skill development gained through 4-H and other youth development organizations (Maass, Wilken, Jordan, Culen, \& Place, 2006; Miller, \& Bowen, 1993).

Researchers have become increasingly interested in identifying the link between specific life skills development and participation in specific elements within a program. Some examined life skills including decision making, leadership, team work, public speaking, problem solving, and critical thinking. Most studies have suggested a positive correlation between participating in 4-H youth development programs and a growth in the development of participants' life skills. (Boyd, Herring, \& Briers, 1992; Cantrell, Heinsohn, \& Doebler, 1989; Diem, 2004; Fitzpatrick, Gagne, Jones, Lobley, \& Phelps 2005; Fox, Schroeder, \& Lodl, 2003; Mincemoyer, \& Perkins, 2003; Mincemoyer, \& Perkins, 2005; Pennington, \& Edwards, 2006; Radhakrishna, \& Sinasky, 2005; Seevers, \& Dormody, 1994). What these studies do not tell us is the impact on participants over time.

Among all the life skills, judgment and decision-making have received extensive research attention (Albert, \& Steinberg, 2011). The ability to make sensible decisions is one of the key characteristics of the mature adolescent. In addition, since many of the decisions made during adolescence serve to shape, expand or limit the life course (Mann, Harmoni, \& Power, 1989), it is critical to help youth build competence in decision making. Educators agree upon the fact that the decision making process can be taught through special programs or school curriculum. Dybal and Sondag (2000), for example, described a teaching technique that takes students through the steps of a decision making model. The steps include describing the problem, checking influences, identifying alternatives, checking risks and consequences, decision action, and evaluation. The technique advocates for the use of pre-written scenarios and worksheets as teaching aids (Dybdal, \& Sondag, 2000).

The study presented in this article focuses on an important aspect of life-event decision making: consumer decision making. This study will explore the correlation of life skill development of the 4-H Consumer Decision Making (CDM) program participants over time. It is believed that making purchases, either big or small, involves a process parallel to the decision making process. Consumer decision making requires life skills that enables consumers to make wise decisions utilizing a dual-process involving analytical and experiential cognition. The skills needed can be taught and developed through programs tailored to train wise consumers. Olson and Croymans (2008) reported that as a result of participating in the 4-H CDM program, youth are more competent and confident in making consumer decisions. Participants also are more skilled in learning to reason, recognize quality products, and to make decisions based on a given situation.

\section{Program Design}

The 4-H Consumer Decision Making (CDM) program conducted by the University of Minnesota Extension provides a venue for youth to learn and practice the cross-cutting life skill of decision making. The program also incorporates the experiential learning theory "whereby knowledge is created through the transformation of experience," (Kolb, 1984) by bridging the youth's newly acquired knowledge and skills to an awareness and response to local needs. The CDM program continuum includes team practice on the county level with a volunteer coach, regional and state contests, and a state service learning activity which culminates in community service in their 
local county. Additional opportunities include day camps, field trips and project exhibits. At a minimum, participants experience the county judging team practice and may advance to the state contest. Counties with a more comprehensive program have supplemental short term consumer education skill building opportunities such as day camps and field trips that may support and recruit participants to the county judging team practice and multiple levels of contests. Each opportunity is defined below.

County Judging Team Practice - small group youth experience with a volunteer adult relationship, duration varies from site to site, but usually involves multiple sessions starting with learning the decision making judging process and then practicing utilizing real-life scenarios in a judging format.

County Consumer Day Camp - short term site-based day camp experience focusing on consumer skills with age appropriate individual and group work guided by volunteer adult.

County Consumer Education Field Trips - short term experience in the real world of the community with age appropriate individual and group work guided by volunteer adult. The field trip may include a tour of a retail store to learn how stores are laid out and products are marketed, a scavenger hunt, an assigned shopping assignment, or similar activity.

County Fair Consumer Education Project Exhibit - usually an individually developed project representing what the youth has learned about consumerism during the past year of project work that is conference judged and displayed at a county fair.

Consumer Decision Making Judging Contests (County, Regional or State) - a short term experience where individuals typically participate in county judging team practices and then participate in a county, regional, and/or state judging contest which involves individual judging of consumer classes that include a written scenario, criteria, and four options to rank, present oral reasons to defend the decisions made, and participate in a group process activity to demonstrate team decision making skills.

State Consumer Decision Making Educational Activity/Field Trip - a short term experience where individuals learn about issues in our Minnesota communities (such as family food costs, shelter, and clothing), purchasing strategies, and participate in a related shopping or educational experience. Upon completion of the experience the teams defend their purchasing decisions to the large group based on the given criteria and upon return to their home community donate any purchased items to a local non-profit organization.

\section{Purpose}

The purpose of this research project was to determine if there is a correlation between participating in the 4-H CDM Program and participants' life skill development. Our research question was: What impact does participation in the 4-H Consumer Decision Making Program have on the subject's life skill development related to consumerism, over time? Findings may indicate the optimal participant dosage for maximum life skill development... so how much programming is necessary to impact positive influence on life skill development?

Our hypothesis was that participants who were involved as youth in multiple opportunities of the CDM program would report a higher level of positive influence on their life skill development than individuals reporting only minimal involvement in the program. 


\section{Methodology}

\section{Participants}

The target population for the study was alumni of the Minnesota 4-H CDM program. The investigators contacted Extension staff in all 87 Minnesota counties and volunteer 4-H CDM judging coaches for a list of current and past participants of the program. The contact information provided influenced the age range of the respondents. Three hundred and ninety four names were submitted from counties with only 256 having complete contact information. The survey tool and consent materials were mailed in 2008 through the United States Postal Service inviting these individuals to participate in the study. The original hard copy invitation was followed by three postcard reminders and a final hard copy invitation. Twenty five mailings were returned that were non-forward able. Seventy surveys were completed either online or through the mail, resulting in a $30.3 \%$ return rate $(\mathrm{N}=70)$. According to Russ-Eft and Preskill, at least 65 subjects are needed from a 200-people population (32.5\%) to ensure a confidence interval of $90 \%$. The authors accept the $30.3 \%$ response rate as acceptable.

The participants of the study were 70 current and past Minnesota 4-H CDM participants from 16 counties who were involved in the program as youth. The mean age of respondents was 19 with a range of 12 to 39 years of age. All participants were youth at the time of participation in CDM. Eighty three percent of the participants were female and $17 \%$ were male. Eight (11.4\%) of the participants had been enrolled in the 4-H program for 5 years or less; $23(32.9 \%)$ of the participants had been enrolled between 5 and 10 years; and $39(55.7 \%)$ of the participants had been enrolled for 10 or more years. The average number of years individuals participated in each of the eight CDM program opportunities is listed in Table 1.

Table 1

Number of years of participation in CDM program opportunities $(\mathrm{N}=70)$

\begin{tabular}{|l|c|c|}
\hline \multicolumn{1}{|c|}{ CDM program opportunities } & Mean & SD \\
\hline County Judging Team Practice & 3.42 & 2.02 \\
\hline County Consumer Day Camp & 2.89 & 1.27 \\
\hline County Consumer Education Field Trip & 3.19 & 2.37 \\
\hline County Fair Consumer Education Project Exhibit & 2.84 & 1.82 \\
\hline County CDM Judging Contest & 3.67 & 2.37 \\
\hline Regional CDM Judging Contest & 3.30 & 1.99 \\
\hline State CDM Judging Contest & 2.88 & 1.74 \\
\hline State CDM Educational Activity/Field Trip & 2.54 & 1.58 \\
\hline
\end{tabular}

\section{Instrument}

The survey consisted of eleven items. Participants were asked to provide demographic information, including age, gender, county of 4-H membership, number of years enrolled in 4- $\mathrm{H}$, and the project areas they were enrolled in. Participants were also asked the number of years they participated in each of the eight 4-H CDM program opportunities. The survey had 
four Likert-scale questions, which were designed based on the Ak-Sar-Ben 4-H Exhibitor Alumni Survey (Lange, 2004) and Targeting Life Skills Model (Hendricks, 2006). The Likert-scale questions measured the participants' perceptions about their development of twelve life skills, how they gather information prior to making purchases, how often they use the steps of the consumer decision making process when making larger purchases, and the level of influence the program had on positive youth development outcomes (Lerner, et al., 2005; Roth \& BrooksGunn, 2003). The investigators identified twelve life skills from the Targeted Life Skills Model (Hendricks, 2003) that could be influenced by participation in the CDM program. The survey also had four open-ended questions to expand on the Likert-scale question responses. Participants were asked to share the process they use when making a significant and small purchase; the life skills they developed or enhanced through the 4-H CDM program; and the impact the program has had on their life.

The survey was reviewed by the state 4-H CDM committee, state Extension evaluation specialists, and an associate professor of education. The survey was field tested with four program participants to determine readability and usability of the tool. Adjustments to question terminology were made in the pilot survey tool based on the feedback and recommendations of the review team and field test. The study was approved by the Institutional Review Board Human Subjects Committee, University of Minnesota (project \#0802S26023).

\section{Analysis}

All survey responses were inputted into Survey Monkey and coded using the REMARK program. The present analysis focuses on the relationship of the participants' depth of involvement in the program and their perceived influence of life skill development.

One of the Likert-scale questions asked participants to indicate the level of influence participation in the 4-H CDM program had on development of the twelve life skills, using a scale of 1 (no influence) to 4 (major influence). Quantitative data, gathered through the question, was analyzed using the SPSS Statistics version 19.

A separate data set was made for each 4-H CDM program opportunity: the first group being respondents who answered "no" to having participated in the listed opportunity and the second group being respondents who answered "yes" to having participated in the opportunity. Qualitative data, gathered through open-ended questions was analyzed using a theme mapping process. The theme mapping included reviewing all data for common language, then grouping via higher level.

\section{Results}

The self-reported level of influence that participation in the 4-H CDM program had on the development of specific life skills was positive for most of the life skills. The majority of participants reported the program had a "moderate" to "major" influence upon their life skill development in all of the life skills except for "Empathy/Concern for Others." Approximately a third of the participants identified decision making (35.71\%), critical thinking (31.43\%), and useful/marketable skills (30\%) as life skills that the program had a "major influence." Approximately $50 \%$ of the respondents believed the program had at least a "moderate influence" on their life skill development in the areas of: critical thinking, decision making, cooperation/teamwork/contribution to group effort, leadership, planning/organizing, wise use of resources, communication, useful/marketable skills, learning to learn, service learning, and 
accepting differences. Empathy/concern for others was the only skill that the majority of respondents reported "no" or "minor" influence (Table 2).

Table 2

Reported level of influence CDM program had life skill development $(\mathrm{N}=70)$

\begin{tabular}{|c|c|c|c|c|c|}
\hline Life Skill & $\begin{array}{l}\text { No } \\
\text { Influence }\end{array}$ & $\begin{array}{c}\text { Minor } \\
\text { Influence }\end{array}$ & $\begin{array}{l}\text { Moderate } \\
\text { Influence }\end{array}$ & $\begin{array}{c}\text { Major } \\
\text { Influence }\end{array}$ & $\begin{array}{l}\text { Mean } \\
(\mathrm{SD})\end{array}$ \\
\hline Critical Thinking & 0 & $\begin{array}{c}n=4 \\
(5.71 \%)\end{array}$ & $\begin{array}{c}n=44 \\
(62.86 \%)\end{array}$ & $\begin{array}{c}n=22 \\
(31.43 \%)\end{array}$ & $\begin{array}{l}3.26 \\
(0.56)\end{array}$ \\
\hline Decision Making & 0 & $\begin{array}{c}n=5 \\
(7.14 \%)\end{array}$ & $\begin{array}{c}n=40 \\
(57.14 \%)\end{array}$ & $\begin{array}{c}n=25 \\
(35.71 \%)\end{array}$ & $\begin{array}{l}3.29 \\
(0.59)\end{array}$ \\
\hline $\begin{array}{l}\text { Cooperation, Teamwork, } \\
\text { Contribution to Group Effort }\end{array}$ & $\begin{array}{c}n=3 \\
(4.29 \%)\end{array}$ & $\begin{array}{c}n=9 \\
(12.86 \%)\end{array}$ & $\begin{array}{c}n=38 \\
(54.29 \%)\end{array}$ & $\begin{array}{c}n=20 \\
(28.57 \%)\end{array}$ & $\begin{array}{l}3.07 \\
(0.77)\end{array}$ \\
\hline Leadership & $\begin{array}{c}n=2 \\
(2.86 \%)\end{array}$ & $\begin{array}{c}n=11 \\
(15.71 \%)\end{array}$ & $\begin{array}{c}n=43 \\
(61.43 \%)\end{array}$ & $\begin{array}{c}n=14 \\
(20.0 \%)\end{array}$ & $\begin{array}{c}2.99 \\
(0.69)\end{array}$ \\
\hline Planning/Organizing & $\begin{array}{c}n=4 \\
(5.71 \%)\end{array}$ & $\begin{array}{c}n=11 \\
(15.71 \%)\end{array}$ & $\begin{array}{c}n=38 \\
(54.29 \%)\end{array}$ & $\begin{array}{c}n=17 \\
(24.29 \%)\end{array}$ & $\begin{array}{l}2.97 \\
(0.80)\end{array}$ \\
\hline Wise Use of Resources & $\begin{array}{c}n=4 \\
(5.71 \%)\end{array}$ & $\begin{array}{c}n=11 \\
(15.71 \%)\end{array}$ & $\begin{array}{c}n=36 \\
(51.43 \%)\end{array}$ & $\begin{array}{c}n=19 \\
(27.14 \%)\end{array}$ & $\begin{array}{l}3.00 \\
(0.82)\end{array}$ \\
\hline Communication & $\begin{array}{c}n=1 \\
(1.43 \%)\end{array}$ & $\begin{array}{c}n=17 \\
(24.29 \%)\end{array}$ & $\begin{array}{c}n=35 \\
(50.0 \%)\end{array}$ & $\begin{array}{c}n=17 \\
(24.29 \%)\end{array}$ & $\begin{array}{l}2.97 \\
(0.74)\end{array}$ \\
\hline Useful/Marketable Skills & $\begin{array}{c}n=6 \\
(8.57 \%)\end{array}$ & $\begin{array}{c}n=12 \\
(17.14 \%)\end{array}$ & $\begin{array}{c}n=31 \\
(44.29 \%)\end{array}$ & $\begin{array}{c}n=21 \\
(30.0 \%)\end{array}$ & $\begin{array}{l}2.96 \\
(0.91)\end{array}$ \\
\hline Learning to Learn & $\begin{array}{c}n=2 \\
(2.86 \%)\end{array}$ & $\begin{array}{c}n=18 \\
(25.71 \%)\end{array}$ & $\begin{array}{c}n=41 \\
(58.57 \%)\end{array}$ & $\begin{array}{c}n=9 \\
(12.86 \%)\end{array}$ & $\begin{array}{c}2.81 \\
(0.69)\end{array}$ \\
\hline Service Learning & $\begin{array}{c}n=11 \\
(15.71 \%)\end{array}$ & $\begin{array}{c}n=20 \\
(28.57 \%)\end{array}$ & $\begin{array}{c}n=31 \\
(44.29 \%)\end{array}$ & $\begin{array}{c}n=8 \\
(11.43 \%)\end{array}$ & $\begin{array}{c}2.51 \\
(0.90)\end{array}$ \\
\hline Accepting Difference & $\begin{array}{c}n=8 \\
(11.43 \%)\end{array}$ & $\begin{array}{c}n=25 \\
(35.71 \%)\end{array}$ & $\begin{array}{c}n=29 \\
(41.43 \%)\end{array}$ & $\begin{array}{c}\mathrm{n}=8 \\
(11.43 \%)\end{array}$ & $\begin{array}{c}2.53 \\
(0.85)\end{array}$ \\
\hline Empathy/Concern for Others & $\begin{array}{c}n=14 \\
(20.0 \%)\end{array}$ & $\begin{array}{c}n=25 \\
(35.71 \%)\end{array}$ & $\begin{array}{c}n=26 \\
(37.14 \%)\end{array}$ & $\begin{array}{c}n=5 \\
(7.14 \%)\end{array}$ & $\begin{array}{c}2.31 \\
(0.88)\end{array}$ \\
\hline
\end{tabular}

Non-parametric tests for two independent samples were used to analyze the relationship between participation in the CDM program opportunities and self-reported level of influence their participation had on life skill development. The one program opportunity that appears to have influenced the most life skills is the County Fair Consumer Education Project Exhibit. The results indicate that those participating in this opportunity reported a statistically significant influence on the development of a number of life skills, including critical thinking, decision making, leadership, planning/organizing, communication, and accepting differences. 
Participation in a County Consumer Day Camp significantly influenced the development of the service learning and accepting differences life skills. Respondents indicated participation in the State CDM Educational Activity/Field Trip had a significant influence on the life skills of cooperation, service learning, and empathy/concern for others. County Consumer Educational Field Trip, County CDM Judging Contest and Regional CDM Judging Contest had a significant influence on limited areas of life skills development, namely, wise use of resources, accepting differences and critical thinking, respectfully. Opportunities such as County Judging Team Practice and State CDM Judging Contest did not show a significant influence on the development of any life skills (Table 3 ).

Table 3

Reported level of influence CDM program opportunities had on life skill development $(\mathrm{N}=70)$

\begin{tabular}{|c|c|c|c|c|c|c|c|c|c|c|c|c|c|c|c|c|}
\hline \multirow{2}{*}{$\begin{array}{l}\text { Life Skill } \\
\text { p value }\end{array}$} & \multicolumn{2}{|c|}{$\begin{array}{c}\text { County } \\
\text { Judging } \\
\text { Team } \\
\text { Practice }\end{array}$} & \multicolumn{2}{|c|}{$\begin{array}{c}\text { County } \\
\text { Consumer } \\
\text { Day Camp }\end{array}$} & \multicolumn{2}{|c|}{$\begin{array}{l}\text { County } \\
\text { Consumer } \\
\text { Education } \\
\text { Field Trip }\end{array}$} & \multicolumn{2}{|c|}{$\begin{array}{c}\text { County Fair } \\
\text { Consumer } \\
\text { Education } \\
\text { Project } \\
\text { Exhibit }\end{array}$} & \multicolumn{2}{|c|}{$\begin{array}{l}\text { County } \\
\text { Judging } \\
\text { Contest }\end{array}$} & \multicolumn{2}{|c|}{$\begin{array}{c}\text { Regional } \\
\text { Judging } \\
\text { Contest }\end{array}$} & \multicolumn{2}{|c|}{$\begin{array}{c}\text { State } \\
\text { Judging } \\
\text { Contest }\end{array}$} & \multicolumn{2}{|c|}{$\begin{array}{c}\text { State } \\
\text { Educational } \\
\text { Activity/ } \\
\text { Field Trip }\end{array}$} \\
\hline & $\begin{array}{l}Y e s \\
n=52\end{array}$ & $\begin{array}{l}\mathrm{Nb} \\
\mathrm{n}=18\end{array}$ & $\begin{array}{l}\text { Yes } \\
n=9\end{array}$ & $\begin{array}{l}\mathrm{Nb} \\
\mathrm{n}=61\end{array}$ & $\begin{array}{l}\text { Yes } \\
n=16 \\
\end{array}$ & $\begin{array}{l}\mathrm{Nb} \\
\mathrm{n}=54\end{array}$ & $\begin{array}{l}\text { Yes } \\
n=25\end{array}$ & $\begin{array}{l}\mathrm{Nb} \\
\mathrm{n}=45\end{array}$ & $\begin{array}{l}\text { Yes } \\
n=43\end{array}$ & $\begin{array}{l}\mathrm{Nb} \\
\mathrm{n}=\mathbb{Z}\end{array}$ & $\begin{array}{l}\text { Yes } \\
n=30\end{array}$ & $\begin{array}{l}\mathrm{Nb} \\
\mathrm{n}=40\end{array}$ & $\begin{array}{l}\text { Yes } \\
n=64\end{array}$ & $\begin{array}{l}\mathrm{Nb} \\
\mathrm{n}=6\end{array}$ & $\begin{array}{l}\text { Yes } \\
n=26\end{array}$ & $\begin{array}{l}\mathrm{Nb} \\
\mathrm{n}=44\end{array}$ \\
\hline $\begin{array}{l}\text { Critical } \\
\text { Thinking }\end{array}$ & \multicolumn{2}{|c|}{.476} & \multicolumn{2}{|c|}{.083} & \multicolumn{2}{|c|}{.299} & \multicolumn{2}{|c|}{$.001^{*}$} & \multicolumn{2}{|c|}{.147} & \multicolumn{2}{|c|}{$.007 *$} & \multicolumn{2}{|c|}{.182} & \multicolumn{2}{|c|}{169} \\
\hline $\begin{array}{l}\text { Decision } \\
\text { Making }\end{array}$ & \multicolumn{2}{|c|}{.266} & \multicolumn{2}{|c|}{.881} & \multicolumn{2}{|c|}{.473} & \multicolumn{2}{|c|}{$.016^{*}$} & \multicolumn{2}{|c|}{.449 } & \multicolumn{2}{|c|}{.973} & \multicolumn{2}{|c|}{.151} & \multicolumn{2}{|c|}{.136} \\
\hline Cooperation & \multicolumn{2}{|c|}{.704} & \multicolumn{2}{|c|}{.276} & \multicolumn{2}{|c|}{.154} & \multicolumn{2}{|c|}{.052} & \multicolumn{2}{|c|}{.597} & \multicolumn{2}{|c|}{.645} & \multicolumn{2}{|c|}{.270} & \multicolumn{2}{|c|}{$.010^{*}$} \\
\hline Leadership & \multicolumn{2}{|c|}{.610} & & 76 & & & & $27 *$ & .8 & & & 79 & & 69 & & 73 \\
\hline $\begin{array}{l}\text { Planning/ } \\
\text { Organizing }\end{array}$ & & & & 51 & & & & $15^{*}$ & .08 & & & 32 & & 30 & & 38 \\
\hline $\begin{array}{l}\text { Use of } \\
\text { Resources }\end{array}$ & & & & & & & & 06 & .1 & & & 17 & & 23 & & 07 \\
\hline $\begin{array}{l}\text { Communi- } \\
\text { cation }\end{array}$ & & & & 31 & & & & 03* & .6 & & & 87 & & 0 & & 59 \\
\hline $\begin{array}{l}\text { Useful/ } \\
\text { Marketable } \\
\text { Skills }\end{array}$ & & & & & & & & 05 & .4 & & & 58 & & 36 & & 33 \\
\hline $\begin{array}{l}\text { Learning to } \\
\text { Learn }\end{array}$ & & & & & & & & 79 & .7 & & & 73 & & 58 & & 97 \\
\hline $\begin{array}{l}\text { Service } \\
\text { Learning }\end{array}$ & & & & & & & & 43 & .4 & & & 20 & & 32 & .02 & \\
\hline $\begin{array}{l}\text { Accepting } \\
\text { Differences }\end{array}$ & & & & & & & & $42 *$ & .03 & & & 45 & & 93 & & 11 \\
\hline $\begin{array}{l}\text { Empathy/ } \\
\text { Concern for } \\
\text { Others }\end{array}$ & & & & 28 & & & & 43 & .6 & & & 00 & & 63 & & \\
\hline
\end{tabular}

$* \mathrm{p}<0.05$ (statistically significant)

To determine the amount of dosage that has the most influence on life skill development a nonparametric analysis was used to examine the differences between four groups of individuals who participated in different numbers of opportunities. Individuals that reported participating in a multiple number of CDM program opportunities ranging from 3, 4-5, and 6-8 were compared to individuals participating in a minimum of $1-2$ opportunities. It was found that those who 
participated in more opportunities (4-5 and 6-8) reported a significant influence in the development of more life skills than those with minimal participation in only 1-2 opportunities.

All participants with a higher level of participation (3, 4-5 and 6-8 opportunities) reported participation had a significant influence on the life skill of accepting differences, while participation in 4-8 opportunities had a significant influence on critical thinking. Involvement in 3 opportunities compared to only 1-2 opportunities also showed a significant influence on the leadership life skill. Individuals in 4-5 opportunities also reported decision making and communication life skills were significantly influenced by participation. Participation in 6-8 opportunities compared to 1-2 opportunities had the greatest impact with significance reported for 6 life skills; critical thinking, leadership, planning/organizing, wise use of resources, useful/marketable skills, and accepting differences.

Table 4

Reported influence of life skill development at varying levels of participation

\begin{tabular}{|c|c|c|c|}
\hline Life Skill & $\begin{array}{l}\text { Comparison } \\
\text { between } \\
\text { participation in } \\
1-2 \\
\text { opportunities } \\
\text { ( } n=18) \text { and } 3 \\
\text { opportunities } \\
(n=16) \\
\text { p-value }\end{array}$ & $\begin{array}{l}\text { Comparison } \\
\text { between } \\
\text { participation in } \\
1-2 \\
\text { opportunities } \\
(n=18) \text { and 4-5 } \\
\text { opportunities } \\
\text { ( } n=27) \\
\text { p-value }\end{array}$ & $\begin{array}{l}\text { Comparison } \\
\text { between } \\
\text { participation in } \\
1-2 \\
\text { opportunities } \\
(n=18) \text { and } 6-8 \\
\text { opportunities } \\
(n=9) \\
\\
p \text {-value }\end{array}$ \\
\hline Critical Thinking & 1.00 & $.008 *$ & $.004 *$ \\
\hline Decision Making & .707 & $.017^{*}$ & .088 \\
\hline $\begin{array}{l}\text { Cooperation, Teamwork, Contribution to } \\
\text { Group Effort }\end{array}$ & .104 & .098 & .068 \\
\hline Leadership & $.041^{*}$ & .156 & $.003 *$ \\
\hline Planning/Organizing & .068 & .170 & $.003 *$ \\
\hline Wise Use of Resources & .984 & .717 & $.016^{*}$ \\
\hline Communication & .272 & $.026 *$ & .083 \\
\hline Useful/Marketable Skills & .272 & .712 & $.011^{*}$ \\
\hline Learning to Learn & .712 & .778 & .466 \\
\hline Service Learning & .627 & .760 & .187 \\
\hline Accepting Difference & $.020 *$ & $.030 *$ & $.002 *$ \\
\hline Empathy/Concern for Others & .247 & .554 & .219 \\
\hline
\end{tabular}

$* \mathrm{P}<0.05$ (statistically significant) 
Age of participants at the time of the survey indicated a difference in reported level of life skill development. Data comparing participants age 18 and under with those 19 and older at time of reporting, indicated that the CDM program significantly influenced four life skills; critical thinking, learning to learn, service learning, and empathy/concern for others. When participants age 21 \& under were compared with those ages 22 \& over at time of reporting, a significant difference on influence on life skill development was found in only two areas: service learning and empathy/concern for others.

\section{Table 5}

Reported influence of life skill development by age

\begin{tabular}{|l|l|l|}
\hline Life Skill & $\begin{array}{l}\text { Comparison between } \\
\text { participants 18 \& under } \\
(\mathrm{n}=27) \text { and those who 19 \& } \\
\text { older }(\mathrm{n}=43) \text { at time of } \\
\text { reporting } \\
\text { p-value }\end{array}$ & $\begin{array}{l}\text { Comparison between } \\
\text { participants 21 \& under }(\mathrm{n}=38) \\
\text { and those 22 \& older }(\mathrm{n}=32) \text { at } \\
\text { time of reporting } \\
\text { p-value }\end{array}$ \\
\hline Critical Thinking & $.032 *$ & .708 \\
\hline Decision Making & .654 & .638 \\
\hline $\begin{array}{l}\text { Cooperation, Teamwork, } \\
\text { Contribution to Group Effort }\end{array}$ & .626 & .138 \\
\hline Leadership & .901 & .326 \\
\hline Planning/Organizing & .868 & .721 \\
\hline Wise Use of Resources & .371 & .802 \\
\hline Communication & .533 & .427 \\
\hline Useful/Marketable Skills & .295 & .353 \\
\hline Learning to Learn & $.039 *$ & .131 \\
\hline Service Learning & $.005 *$ & $.001 *$ \\
\hline Accepting Difference & .822 & .156 \\
\hline Empathy/Concern for Others & $.004 *$ & $.001 *$ \\
\hline P < 0.05 (statistically significant) & & \\
\hline
\end{tabular}

There were 69 responses to the open-ended question "what life skills did you develop or enhance as a result of your participation in the 4-H CDM program?" The responses can be grouped into four categories. There were 32 comments indicating the participants have developed the skills and strategies to make better decisions when making purchases.

Participants also identified several life skills that were developed or enhanced through the CDM program, such as critical thinking; the ability to prioritize and compare items before; and public speaking, communication and teamwork skills. Individuals report participation in the CDM program has equipped them with the skills to think through their needs and make informed decisions about their purchases (Table 6). 


\section{Table 6}

Life skill development through CDM program

\begin{tabular}{|l|l|}
\hline \multicolumn{1}{|c|}{ Category } & \multicolumn{1}{c|}{ Examples of Quotes } \\
\hline $\begin{array}{l}\text { The ability to making better or } \\
\text { wiser decisions ( } \mathrm{n}=32)\end{array}$ & $\begin{array}{l}\text { "I learned to look at products closer so I make the best choice." } \\
\text { "I tend to think things through more thoroughly when I make purchases now. } \\
\text { And find myself asking is this the best choice." } \\
\text { "To make wiser decisions in cost, quality, quantity, etc. whenever I purchase } \\
\text { something." }\end{array}$ \\
\hline $\begin{array}{l}\text { Critical thinking, reasoning, } \\
\text { analyzing skills (n=19) }\end{array}$ & $\begin{array}{l}\text { "I learned about analyzing the products I may buy and how to choose the } \\
\text { best one." } \\
\text { "I developed skills for evaluating different consumer products with regards to } \\
\text { cost, quality, purpose, etc." } \\
\text { "I tend to think things through more thoroughly when I make purchases } \\
\text { now." }\end{array}$ \\
\hline $\begin{array}{l}\text { The ability to prioritize, } \\
\text { comparing items before the } \\
\text { purchase (n=16) }\end{array}$ & $\begin{array}{l}\text { "I learned how to compare items when buying a product and how to rank } \\
\text { them in regards to my needs." } \\
\text { "I am able to compare and contrast many different products and services that } \\
\text { I purchase throughout the day/month." } \\
\text { "Systematic decision making - using pen and paper - writing a priority list of } \\
\text { criteria." }\end{array}$ \\
\hline $\begin{array}{l}\text { Public speaking, communication, } \\
\text { team work skills, confidence } \\
(n=12)\end{array}$ & $\begin{array}{l}\text { "Public Speaking - confidence, organizational skills, timelines" } \\
\text { "My communication skills improved from my participation in the CDM } \\
\text { program." }\end{array}$ \\
\hline
\end{tabular}

\section{Discussion}

Participation in select CDM program opportunities resulted in statistically significant levels of influence in particular life skills. Exhibiting a county fair consumer education project had significant influence on the most life skills; critical thinking, decision making, leadership, plan/ organizing, communication and accepting differences life skills. Participating in the state educational activity/field trip or the county day camp also resulted in influencing more than one life skill. The ability to critically think and make decisions is a desired outcome of a consumer education program.

This study suggests that while basic participation in the CDM program (1-2 opportunities) influences the development of the critical thinking and decision making life skills, participating in multiple program opportunities (6-8) significantly increased the program's level of influence on development of these life skills in addition to leadership, planning/organization, wise use of resources, useful/marketable skills, and accepting differences. This strongly supports building the breadth of the program to maximize the cumulative effect on the development of the identified life skills with significant relationships. Opportunities for progressive learning are important because they allow youth to maintain their interest and continue their involvement as they get older (Walker, 2006). The county consumer day camp and county consumer education field trip are two entry level, short term opportunities with reported significant influence on life skills. Although participants of such opportunities have no obligation to continue with the CDM program, participation may increase interest in the topic and of other opportunities in the program. The county consumer field trip was the only opportunity that had a significant 
influence on the development of the wise use of resources life skill, which may imply that the hands-on nature of a field trip in the real-life community context helps to build this skill.

For some, awareness of the CDM program is followed by interest in individual exploration of and enrollment in the 4-H Consumer Education project. Study findings of significance on the program's influence of county fair consumer education project exhibits in the development of critical thinking, decision making, and communication life skills match the objectives of the CDM program as well known elements of mastery in individual project work success. Exhibiting a project at the county fair allows one to not only share knowledge, but at higher levels of learning, allows one to synthesize their comprehension and application of knowledge gained and express this through a new product/exhibit. Connecting multiple learning opportunities within a program to a 4-H project supports higher level of cognitive learning.

Life skills are learned by being involved with a specific 4-H project over time (Fitzpatrick, et al., 2005). This study's respondents' reported being enrolled in the 4-H program for an average of 8 years. The CDM program participants report being involved in county CDM judging team practices for an average of 3.42 years and in the state consumer contest for an average of 2.88 years. Such data suggests that multiple progressive learning opportunities exist for some participants in the CDM program. The significant findings found for participants of these multiple progressive learning opportunities encourage the development of such a full program model to reach a higher level of influence upon life skill development.

This study finds promising results for life skill building through CDM yet caution is required since there was not a control group to compare to youth who did not participate in 4-H programming. Also, alumni can control for their additional life experiences and opportunities that would have built their life skills in other ways.

To ensure the greatest impact on life skill development, this study supports the creation of a program delivery model with multiple opportunities for participation. Key opportunities that support positive youth development include encouraging participants to continue their exploration of a topic and their mastery through developing related county fair exhibits. The authors feel both of these findings can apply to the vast range of 4-H youth development program topics. Youth development programs that do not have a county fair venue for youth to exhibit a project are encouraged to identify showcase opportunities for youth to develop, share and display projects that represents what they have learned about consumerism. Such venues might include sharing their learning at a parent night, displaying an exhibit or poster at the local library, or communicating what they have learned through traditional or social media, including radio, newspaper or newsletter article, You Tube, Facebook, or Twitter.

\section{References}

Albert, D., \& Steinberg, L. (2011). Judgment and decision making in adolescence. Journal of Research on Adolescence, 21: 211-224. doi: 10.1111/j.1532-7795.2010.00724.

Astroth, K.A., \& Haynes, G.W. (2002). More than cows and cooking: Newest research shows the impact of 4-H. Journal of Extension, 40(4), Retrieved online February 20, 2011 from

http://www.joe.org/joe/2002august/a6.php 
Boleman, C.T., Cummings, S.R., \& Briers, G.E. (2004). Parents' perceptions of life skills gained by youth participating in the 4-H beef project. Journal of Extension, 42(5). Retrieved online February 20, 2011 at: http://www.joe.org/joe/2004october/rb6.php

Boyd, B.L., Herring, D.R., \& Briers, G.E. (1992). Developing life skills in youth. Journal of Extension, 30(4). Retrieved online February 20, 2011 at:

http://www.joe.org/joe/1992winter/a4.php

Cantrell, J., Heinsohn, A.L., \& Doebler, M.K. (1989). Is it worth the costs? Journal of Extension, 2オ1). Retrieved online February 20, 2011 at: http://www.joe.org/joe/1989spring/a4.php

Diem, K.G. (2004). The learn-by-doing approach to life skill development. New Brunswick, NJ: N.J. Agricultural Experiment Station. Retrieved online February 22, 2011 at: http://njaes.rutgers.edu/pubs/publication.asp?pid=fs891

Dybdal, L., \& Sondag, K.A. (2000). Developing decision-making skills through the use of critical incidents. [Abstract]. Journal of Health Education, 31(2).

Fitzpatrick, C., Gagne, K.H., Jones, R., Lobley, J., \& Phelps, L. (2005). Life skills development in youth: Impact research in action. Journal of Extension, 43(3). Retrieved online February 19, 2011 at: http://www.joe.org/joe/2005june/rb1.php

Fox, J., Schroeder, D., \& Lodl, K. (2003). Life skill development through 4-H clubs: The perspective of 4-H alumni. Journal of Extension, 41(6). Retrieved online February 20, 2011 at: http://www.joe.org/joe/2003december/rb2.php

Goodwin, J., Barnett, C., Pike, M., Peutz, J., Lanting, R., \& Ward, A. (2005). Idaho 4-H impact study. Journal of Extension, 43(4). Retrieved online February 19, 2011 at:

http://www.joe.org/joe/2005auqust/a4p.shtml

Hendricks, P.A. (2006). Developing youth curriculum using the targeting life skill model: Incorporating developmentally appropriate learning opportunities to assess impact of life skill development. Ames Iowa: Iowa State University Extension.

Klem, M.D., \& Nicholson, D.J. (2008). Proven effectiveness of Missouri 4-H camps in developing life skills in youth. Journal of Youth Development, 2(3). Retrieved online March 1, 2011 at: http://data.memberclicks.com/site/nae4a/JYD 070203final.pdf

Kolb, D.A. (1984). Experiential learning: Experience as the source of learning and development. Englewood Cliffs, NJ: Prentice Hall. Retrieved from http://www.learningfromexperience.com/images/uploads/process-of-experiential-learning.pdf

Lange, K. (2004). Ak-Sar-Ben 4-H exhibitor alumni survey. Unpublished manuscript, University of Nebraska, Omaha, Nebraska. 
Lerner, R.M., Lerner, J.V., Almerigi, J.B., Theokas, C., Phelps, E., Gestsdottir, S., et al. (2005). Positive youth development, participation in community youth development programs, and community contributions of fifth-grade adolescents: Findings from the first wave of the 4-H study of positive youth development. Journal of Early Adolescence, 25, 17-71. Retrieved online March 3, 2011 at: http://jea.sagepub.com.floyd.lib.umn.edu/content/25/1/17.full.pdf+html

Maass, S.E., Wilken, C.S., Jordan, J., Culen, G., \& Place, N. (2006). A comparison of 4-H and other youth development organizations in the development of life skills. Journal of Extension, 44(5). Retrieved online February 19, 2011 at: http://www.joe.org/joe/2006october/rb2.php

Mann, L., Harmoni, R., \& Power, C. (1989). Adolescent decision-making: The development of competence. Journal of Adolescence, 12(3), 265-278. Retrieved online February 20, 2011 at: http://www.sciencedirect.com/science/article/pii/0140197189900778

McKinley, S.K. (1999). 4-H alumni perceptions regarding the impact of the Indiana 4-H program. ETD Collection for Purdue University. Retrieved online March 2, 2011 at: http://docs.lib.purdue.edu/dissertations/AAI9951991/

Miller, J.P., \& Bowen, B.E. (1993). Competency, coping, and contributory life skills development of early adolescents. Journal of Agricultural Education, 34(1), 68-76. Retrieved online March 2, 2011 at: http://202.198.141.77/upload/soft/0000/34-01-68.pdf

Mincemoyer, C.C., \& Perkins, D.F. (2003). Assessing decision-making skills of youth. The Forum for Family and Consumer Issues, 8(1). Retrieved online March 1, 2011 at:

http://ncsu.edu/ffci/publications/2003/v8-n1-2003-january/ar-1-accessing.php

Mincemoyer, C.C., \& Perkins, D.F. (2005). Measuring the impact of youth development programs: A national on-line youth life skills evaluation system. The Forum for Family and Consumer Issues (FFCI), 10(2). Retrieved online March 1, 2011 at: http://www.ncsu.edu/ffci/publications/2005/v10-n2-2005-october/pa-1-measuring.php

Mulroy, M.T., \& Kraimer-Rickaby, L. (2006). The impact and sustainability of 4-H youth development programs. University of Connecticut, Center for Applied Research. Retrieved online March 3, 2011 at: http://downloads.cas.psu.edu/4h/EvalSynFinalReport.pdf

National 4-H Council. (2011). About 4-H. Retrieved from: www.4-H.org/about/

Nash, S.A., \& Sant, L.L. (2005). Life-skill development found in 4-H animal judging. Journal of Extension, 43(2). Retrieved online February 22, 2011 at:

http://www.joe.org/joe/1996april/rb2.php

Olson, C.A., \& Croymans, S.R. (2008). Strengthening 4-H youth consumer decision-making skills: Contest to community service. Journal of Extension, 46(1)

Pennington, P., \& Edwards, M.C. (2006). Former 4-H key club members' perceptions of the impact of "giving" life skills preparation on their civic engagement. Journal of Extension, 44(1). Retrieved online March 3, 2011 at: http://www.joe.org/joe/2006february/a7.php 
Radhakrishna, R.B., \& Sinasky, M. (2005). 4-H experiences contributing to leadership and personal development of 4-H alumni. Journal of Extension, 43(6). Retrieved online March 1, 2011 at: http://www.joe.org/joe/2005december/rb2p.shtml

Roth, J., \& Brooks-Gunn, J. (2003). What exactly is a youth development program? Answers from research and practice. Applied Developmental Science, 7, 94-111. Retrieved online March 4, 2011 at:

http://web.ebscohost.com.floyd.lib.umn.edu/ehost/pdfviewer/pdfviewer?hid=13\&sid=2438d504 -16bf-4fb9-875d-a81a8958f39f\%40sessionmgr15\&vid=3

Roth, J.L., \& Brooks-Gunn, J. (2003). Youth development programs: Risk, prevention and policy. Journal of Adolescent Health, 32(3), 170-182. Retrieved online March 4, 2011 at: http://oklahoma4h.okstate.edu/projects/literature/roth brooks gunn.pdf http://www.felipepalazon.edu.bo/portal/wp-content/uploads/2011/02/positive-youthdevelopment.pdf

Rusk, C.P., Martin, C.A., Talbert, B.A., \& Balschweid, M.A. (2002). Attributes of Indiana's 4-H livestock judging program. Journal of Extension, 40(2). Retrieved online February 22, 2011 at: http://www.joe.org/joe/2002april/rb5.php

Seevers, B., \& Dormody, T.J. (1994). Predicting youth life leadership skills development among senior 4-H members: A tri-state study. Journal of Agricultural Education, 35(3), 64-69. Retrieved online February 20, 2011 at: http://pubs.aged.tamu.edu/jae/pdf/Vol35/35-03-64.pdf

Stafford, J.R., Boyd, B.L., \& Lindner, J.R. (2003). The effects of service learning on leadership life skills of 4-H members. Journal of Agricultural Education, 44(1), 10-21. Retrieved March 1, 2011 from: http://www.jae-online.org/attachments/article/354/44-01-10.pdf

Walker, J. (2006). Intentional youth programs: Taking theory to practice. New Directions for Youth Development, 112, 75-92.

Ward, C.K. (1996). Life skill development related to participation in 4-H animal science projects. Journal of Extension, 34(2). Retrieved online February 19, 2011:

http://www.joe.org/1996april/rb2.php

(C) Copyright of Journal of Youth Development Bridging Research and Practice. Content may not be copied or emailed to multiple sites or posted to a listserv without copyright holder's express written permission. Contact Editor at: patricia.dawson@oregonstate.edu for details. However, users may print, download or email articles for individual use. 